\title{
Evaluating local e-government maturity in selected Iberoamerican countries
}

\author{
Gustavo Gouvêa Maciel \\ Department of Social, Political and \\ Territorial Sciences \\ University of Aveiro \\ Aveiro, Portugal \\ gustavo.maciel@ua.pt
}

\author{
Hélder Gomes \\ Águeda School of Technology and \\ Management / Institute of \\ Electronics and Telematics of Aveiro \\ University of Aveiro \\ Aveiro, Portugal \\ helder.gomes@ua.pt
}

\author{
Gonçalo Paiva Dias \\ Águeda School of Technology and \\ Management / Research Unit on \\ Governance, Competitiveness and \\ Public Policies \\ University of Aveiro \\ Aveiro, Portugal \\ gpd@ua.pt
}

\begin{abstract}
This paper describes an exploratory study aiming to assess e-government maturity of municipalities in selected Iberoamerican countries: Andorra, Argentina, Brazil, Chile, Colombia, Portugal and Spain. A geographical criterion was adopted to select the countries, and a demographic criterion was adopted to define the municipalities observed within those countries. Moreover, a three-dimensional maturity model was used to categorize and evaluate each municipal website. Then, we conclude that local e-government still has a substantial room for improvement in the community, or at least in the studied countries, and that population density seems to be associated with the preliminary results for local e-government maturity.
\end{abstract}

Keywords - e-government; local government; maturity; population density; Iberoamerican countries.

\section{INTRODUCTION}

Nowadays, technology acts as an undeniable democratic instrument of information. International research suggests that most transactions between government and citizens (G2C) take place in a local or municipal scale [1]. Nevertheless, local government websites are usually not as well developed as those at the national level [2]. E-government, i.e., "the use of information technology to support government operations, engage citizens, and provide government services" [3], affects the consolidation of democracy as a whole. E-government G2C transactions usually begin with an informational approach and then move towards complex interaction [3], [4].

Local e-government, in a widely used extension of the concept [3], [5], still intrigues scholars, especially in the case of municipal website maturity. Many efforts were done during the last two decades in this fruitful field of study, but most of them only tried to evaluate and compare electronic G2C transactions by analyzing this phenomenon in a subnational level [2], [4], [6]-[11]. Some relevant contributions were also made by comparing local websites in a cross-national perspective, as we can see in [12], [13]. However, most studies remain focusing a traditional approach: a cross-national e-government evaluation of the higher administrative level of organization [14]-[16].

For more information about e-government, its local implementations, consequences and implications see also [17][30].
In this sense, this paper aims to present a preliminary comparison of local e-government maturity among selected Andorran, Argentinian, Brazilian, Chilean, Colombian, Portuguese and Spanish municipalities. A three-dimensional maturity model was used [4] and a promising variable to explain our results was identified: the population density in municipal areas, i.e., the number of inhabitants per square kilometer.

The remaining of this paper is organized as follows. First, we define the methods used. Second, we present the results and discuss them in three different perspectives: (i) by drawing a cross-national evaluation, (ii) by considering all municipalities as a single group of study, and (iii) by clustering the observations in population density groups. Finally, we contextualize the limitations of the work and present our conclusions about local e-government maturity for this particular group of countries.

\section{METHODS}

The studied countries were selected to assure geographic diversity within Iberoamerica. Andorra, Spain and Portugal cover almost all of the Iberian Peninsula. Argentina, Brazil, Chile and Colombia present a distinctive perspective of location among South America because they increase regional diversity by offering a wide range of directions - from north (Colombia) to south (Argentina) and from east (Brazil) to west (Chile).

A demographic criterion was adopted to select the three most populous and the three less populous capital municipalities of the first-level administrative subdivisions of the previous countries. In this sense, we accessed 42 official municipal websites to evaluate their respective maturity by considering only information and services publicly available. In addition, only official national statistics were used to present populational and spatial data in this paper [31]-[37]. Thereto, we considered the most recent estimations for municipal population, except for Argentina (for which data from the 2010 census was used).

In this paper, we decided to use a website content evaluation to characterize e-government development because of its alignment with the previous works carried out in this field, especially in Portugal [4], [7], [9], [26]. For this purpose, websites were classified according to a multidimensional maturity model, which is largely supported by a great number of e-government scholars [4], [7], [9], [12], [28]-[30]. We decided to use the methodology proposed by [4], which encompass three 
complementary dimensions: online information (Information), online services (Service) and online participation (Participation). Nevertheless, some specific modifications were made to expand this methodology, originally designed to fit the Portuguese reality. Table I shows the three-dimensional methodology adapted for our Iberoamerican analysis.

TABLE I. THREE-DIMENSIONAL MUNICIPAL WEBSITE EVALUATION

\begin{tabular}{|c|l|}
\hline Dimensions & \multicolumn{1}{c|}{ Evaluated content } \\
\hline \multirow{3}{*}{ Information } & $\begin{array}{l}\text { General Information, Documents for public access, } \\
\text { Text based search tools, Semantic search tools, Real- } \\
\text { time citizen support, News services register, Presence in } \\
\text { social networks, Compliance with accessibility rules, } \\
\text { Privacy Policy, Multilingual function, Availability of } \\
\text { consolidated public transparency webpage }\end{array}$ \\
\hline Service & $\begin{array}{l}\text { Information on services, Query status of service } \\
\text { provision, Form submission, Complete online } \\
\text { transaction, Public online payment information, } \\
\text { Electronic authentication }\end{array}$ \\
\hline Participation & $\begin{array}{l}\text { Complaints and/or suggestions submission, opinion or } \\
\text { free discussion participation, Public discussion } \\
\text { participation, participatory budgets }\end{array}$ \\
\hline
\end{tabular}

a. This is an adapted usage of the three-dimensional maturity evaluation proposed by [4]. Contents in bold were part of its original formulation.

This three-dimensional model represents a path to state that e-government is not linear [27]. Each dimension can be developed simultaneously and independently. In this sense, "results in one dimension do not necessarily depend on good results in the others" [4] and websites can produce completely different solutions to enhance $\mathrm{G} 2 \mathrm{C}$ transactions that lead to the same level of website maturity.

Considering this approach, we verified if these municipalities fulfilled each dimensional requisite by simply accessing their websites. The electronic addresses of the pages were annotated whenever evidence of compliance with the characteristics in Table I were found.

Another essential task to construct this methodological approach is to define the calculation method used. The Municipal Website Maturity Index (MWM) presents a score range that varies from 0 - minor score - to 1 - maximum score and considers the particularities illustrated in Table II.

TABLE II. MWM INDEX CALCULATION METHOD

\begin{tabular}{|c|c|c|}
\hline Dimensions & Calculus & Range of variation \\
\hline Information & \multirow{3}{*}{$\begin{array}{c}\text { For each dimension: } \\
\text { (number of observed contents) } \mathrm{x} \\
{[(1 / 3) / \text { (total number of contents }} \\
\text { available for this dimension)] }\end{array}$} & \multirow{3}{*}{$\begin{array}{l}\text { Values for each } \\
\text { dimension vary from } \\
0 \text { to } 0.33 \text {, where } 0 \\
\text { represents the lowest } \\
\text { score and } 0.33 \text {, the } \\
\text { highest. }\end{array}$} \\
\hline Service & & \\
\hline Participation & & \\
\hline $\begin{array}{l}\text { MWM } \\
\text { Final Result }\end{array}$ & Info. + Serv. + Part. & $\begin{array}{l}\text { Final Result varies } \\
\text { from } 0 \text { to } 1 \text {, where } 0 \\
\text { represents the lowest } \\
\text { score and } 1 \text {, the } \\
\text { highest. }\end{array}$ \\
\hline
\end{tabular}

The main goal of this calculation is to give the same weight to each dimension. Therefore, this approach guarantees that there is no overvalued dimension in the composition of the MWM Final Result.

Moreover, we also clustered the results by population density groups. A simple linear regression model connecting this demographic variable with MWM Final Results. For this purpose, Table III categorizes each density group and enables us to evaluate this event statistically.

TABLE III. POPULATION DENSITY GROUPS OF EVALUATION

\begin{tabular}{|c|c|}
\hline Dimensions & Range of analysis (in people//km²) \\
\hline Ultra-high density & {$[5000,+\infty[$} \\
\hline Very high density & {$[500,5000[$} \\
\hline High density & {$[50,500[$} \\
\hline Moderate density & {$[10,50[$} \\
\hline Low density & {$[0,10[$} \\
\hline
\end{tabular}

Finally, websites were accessed between September $15^{\text {th }}$, 2014 and January $24^{\text {th }}$, 2015, which means that any unavailability reported after this period was not considered.

\section{RESULTS AND DISCUSSION}

As a preliminary approach, we grouped all the MWM results by countries. Fig. 1 shows a comparative evaluation of nations, its MWM average scores and amplitudes. Colombia presented the best average results $(0.59)$, followed by Spain $(0.57)$ and Portugal (0.53). On the other side, Andorra (0.35), Argentina, and Brazil (0.47) had the lowest grades. Chile reached exactly the global average score, when considering the group as a whole.

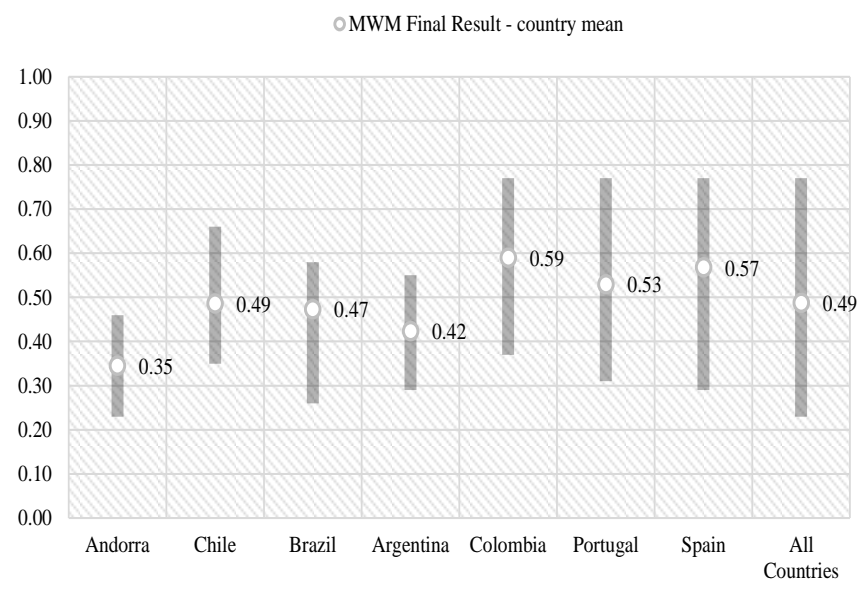

Figure 1. MWM Final Results by country mean and their respective range.

Looking at the results on each dimension, Colombia had the highest scores in Information (0.24) and Participation (0.24). On the other hand, Chile scored higher $(0.18)$ than any other country in Service. Fig. 2 illustrates the dimensional differences between the studied Iberoamerican nations. 


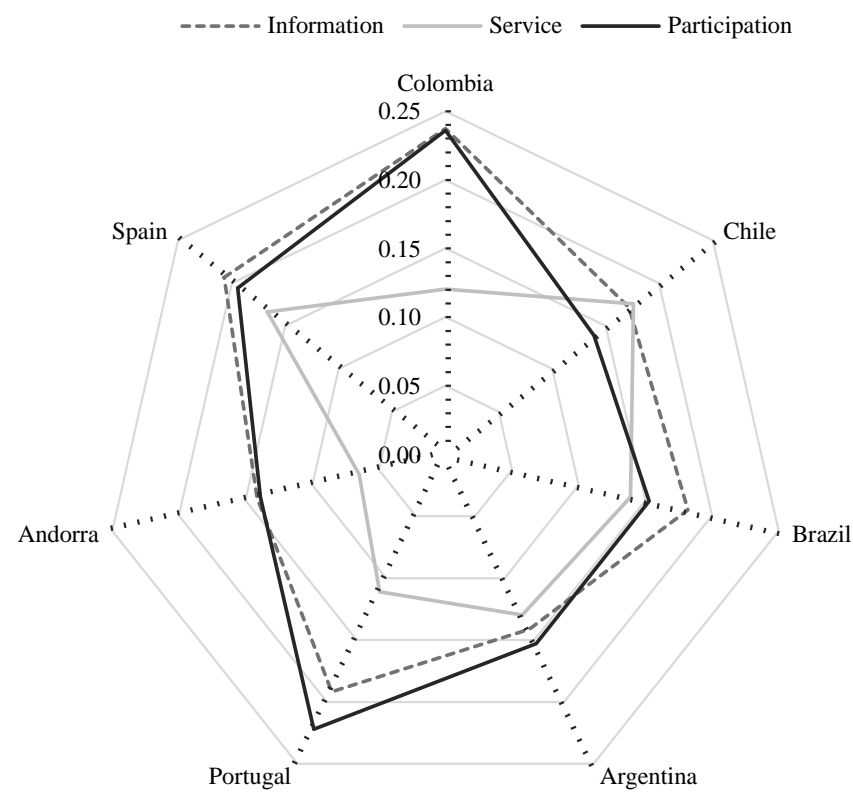

Figure 2. Results in the Information, Service and Participation dimensions by country mean.

Other way of looking into the results is by focusing on local governments, regardless of their country. In this sense, we present the five highest scores and the five lowest scores obtained for each dimension and for the MWM Final Results (Tables IV, V, VI and VII)

TABLE IV. RESULTS IN THE INFORMATION DIMENSION (HIGHLIGHTS)

\begin{tabular}{|cc|c|cc|c|}
\hline \multicolumn{2}{|c|}{ Highest scores $^{\text {a }}$} & \multicolumn{3}{c|}{ Lowest scores $^{\text {a }}$} \\
\hline \multicolumn{2}{|c|}{ Municipality } & Score & Municipality & Score \\
\hline Madrid & ESP & 0.30 & Escaldes-Engordany & AND & 0.09 \\
Mitú & COL & 0.27 & Santa Rosa & ARG & 0.09 \\
Puerto Carreño & COL & 0.27 & Valparaíso & CHL & 0.09 \\
Valencia & ESP & 0.27 & Coimbra & POR & 0.09 \\
Lisboa & POR & 0.27 & Viedma & ARG & 0.09 \\
\hline \multicolumn{2}{|r|}{} & La Plata & ARG & 0.06 \\
\hline
\end{tabular}

a. All municipalities with the same score were considered to construct this table.

TABLE V. RESULTS IN THE SERVICE DIMENSION (HIGHLIGHTS)

\begin{tabular}{|c|c|c|c|c|c|}
\hline \multicolumn{3}{|c|}{ Highest scores $^{\text {a }}$} & \multicolumn{3}{|c|}{ Lowest scores ${ }^{\text {a }}$} \\
\hline \multicolumn{2}{|c|}{ Municipality } & \multirow{2}{*}{$\begin{array}{c}\text { Score } \\
0.28\end{array}$} & \multicolumn{2}{|l|}{ Municipality } & \multirow{2}{*}{$\begin{array}{c}\text { Score } \\
0.06\end{array}$} \\
\hline Coyhaique & $\mathrm{CHL}$ & & Andorra la Vella & AND & \\
\hline Cali & $\mathrm{COL}$ & 0.28 & Escaldes-Engordany & AND & 0.06 \\
\hline Valencia & ESP & 0.28 & Encamp & AND & 0.06 \\
\hline Temuco & CHL & 0.22 & Sant Julià de Lòria & AND & 0.06 \\
\hline Valparaíso & CHL & 0.22 & Ordino & AND & 0.06 \\
\hline Barcelona & ESP & 0.22 & Viedma & $\mathrm{ARG}$ & 0.06 \\
\hline Melilla & ESP & 0.22 & Salvador & BRA & 0.06 \\
\hline \multirow[t]{8}{*}{ Porto } & POR & 0.22 & Antofagasta & CHL & 0.06 \\
\hline & & & Bogotá & $\mathrm{COL}$ & 0.06 \\
\hline & & & Medellín & $\mathrm{COL}$ & 0.06 \\
\hline & & & Ceuta & ESP & 0.06 \\
\hline & & & Mérida & ESP & 0.06 \\
\hline & & & Coimbra & POR & 0.06 \\
\hline & & & Faro & POR & 0.06 \\
\hline & & & Évora & POR & 0.06 \\
\hline
\end{tabular}

a. All municipalities with the same score were considered to construct this table.
TABLE VI. RESULTS IN THE PARTICIPATION DIMENSION (HIGHLIGHTS)

\begin{tabular}{|c|c|c|c|c|c|}
\hline \multicolumn{3}{|c|}{ Highest scores ${ }^{a}$} & \multicolumn{3}{|c|}{ Lowest scores ${ }^{\text {a }}$} \\
\hline \multicolumn{2}{|c|}{ Municipality } & \multirow{2}{*}{$\begin{array}{c}\text { Score } \\
0.33\end{array}$} & \multicolumn{2}{|l|}{ Municipality } & \multirow{2}{*}{$\begin{array}{c}\text { Score } \\
0.08\end{array}$} \\
\hline Barcelona & ESP & & Andorra la Vella & AND & \\
\hline Lisboa & POR & 0.33 & Escaldes-Engordany & AND & 0.08 \\
\hline La Plata & $\mathrm{ARG}$ & 0.25 & Córdoba & COL & 0.08 \\
\hline Medellín & $\mathrm{COL}$ & 0.25 & Santa Rosa & $\mathrm{ARG}$ & 0.08 \\
\hline Cali & $\mathrm{COL}$ & 0.25 & Salvador & BRA & 0.08 \\
\hline Mitú & $\mathrm{COL}$ & 0.25 & Valparaíso & $\mathrm{CHL}$ & 0.08 \\
\hline Inírida & $\mathrm{COL}$ & 0.25 & Punta Arenas & $\mathrm{CHL}$ & 0.08 \\
\hline Puerto Carreño & $\mathrm{COL}$ & 0.25 & Valencia & ESP & 0.08 \\
\hline Madrid & ESP & 0.25 & Ceuta & ESP & 0.08 \\
\hline Mérida & ESP & 0.25 & Faro & POR & 0.08 \\
\hline Porto & POR & 0.25 & & & \\
\hline Ponta Delgada & POR & 0.25 & & & \\
\hline Évora & POR & 0.25 & & & \\
\hline
\end{tabular}

a. All municipalities with the same score were considered to construct this table.

TABLE VII. MWM FINAL RESULTS (HIGHLIGHTS)

\begin{tabular}{|cc|c|cc|c|}
\hline \multicolumn{2}{|c|}{ Highest scores } & \multicolumn{2}{c|}{ Lowest scores } \\
\hline \multicolumn{2}{|c|}{ Municipality } & Score & Municipality & Score \\
\hline Barcelona & ESP & 0.77 & Ceuta & ESP & 0.29 \\
Cali & COL & 0.77 & Santa Rosa & ARG & 0.29 \\
Lisboa & POR & 0.77 & Andorra la Vella & AND & 0.26 \\
Madrid & ESP & 0.72 & Salvador & BRA & 0.26 \\
Porto & POR & 0.71 & Escaldes-Engordany & AND & 0.23 \\
\hline
\end{tabular}

Tables IV to VII expand data analysis to a local perspective by showing specific municipal website characteristics. Almost all top-5 municipalities are Colombian, Spanish or Portuguese, except for the Chilean results in Service dimension and one unique Argentinian observation (La Plata) also for Service. In contrast, when analyzing the lowest scores, we find at least one municipality for each country evaluated.

Fig. 3 and Fig. 4 present dimensional and final MWM municipal scores respectively.

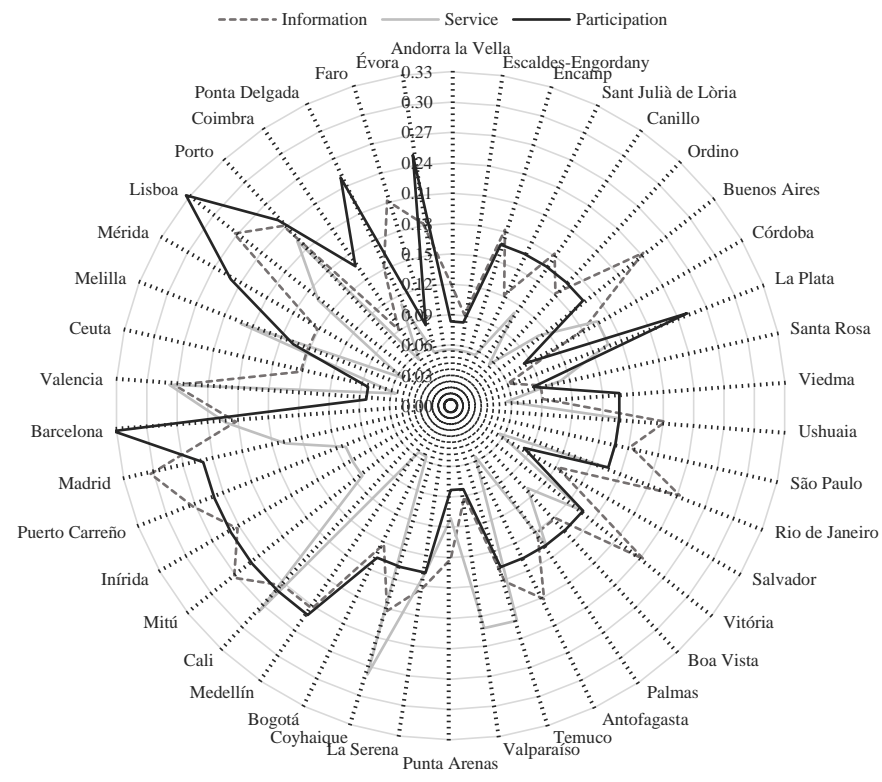

Figure 3. Results in Information, Service and Participation dimensions by municipality. 


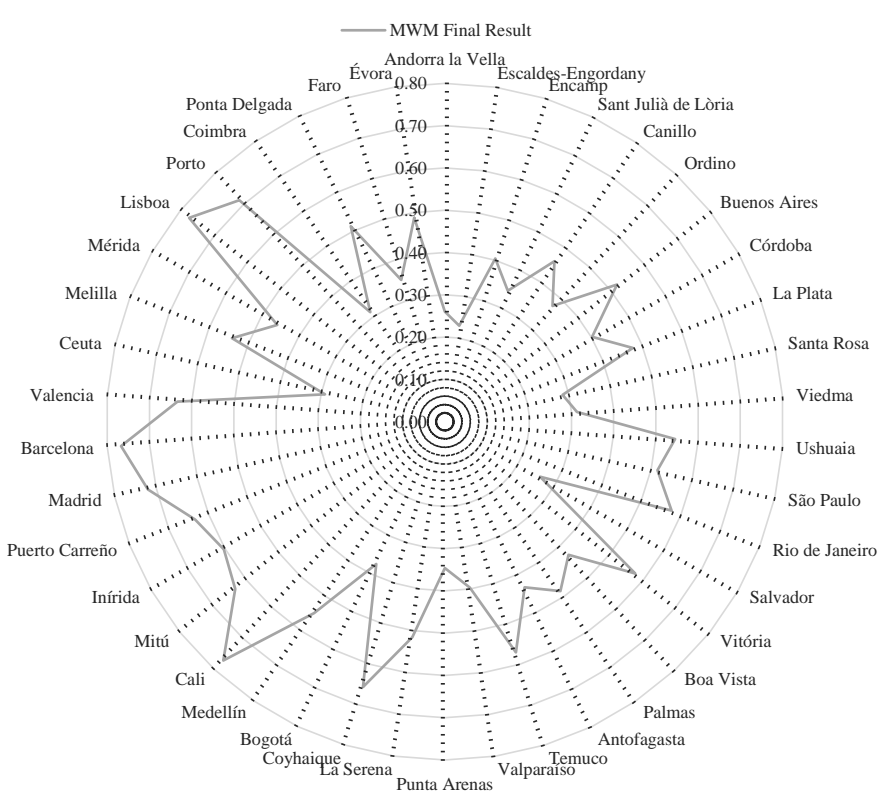

Figure 4. MWM Final Results by municipality.

Moreover, in [4] it was concluded that there is evidence, at least for Portugal, that population density is associated with local e-government maturity. In fact, Fig. 5 suggests a parabolic dynamic for the municipal average scores obtained when grouped by population density. We can see that 'low' density municipalities presented a higher mean when compared to 'moderate', 'high' and 'very high' municipalities. Surprisingly, places with 'low' and 'ultra-high' population density seem to build better local government websites.

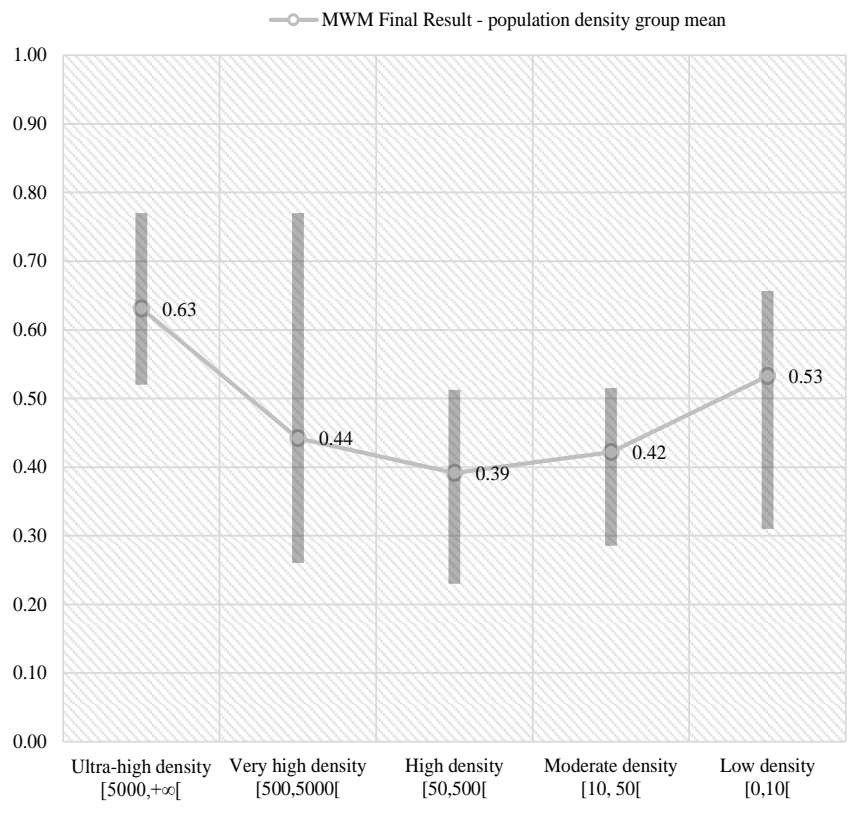

Figure 5. MWM Final Result by population density $\left(\right.$ people $/ \mathrm{km}^{2}$ ) group and their respective range of scores.

This interesting phenomenon needs special attention. In Table VIII it is showed that, even with an extremely reduced sample (only 42 observations), there is a statistical impact of the variable 'population density' (independent variable) on the MWM Final Results per municipality (dependent variable).

TABLE VIII. MWM SIMPLE LINEAR REGRESSION

\begin{tabular}{|c|c|c|c|}
\hline \multicolumn{4}{|c|}{ Dependent variable: MWM Final Results } \\
\hline Model $^{\text {a }}$ & Coefficient & Standard Error & p-value \\
\hline Constant & 0.44644 & 0.0255642 & $<0.00001^{\mathbf{b}}$ \\
\hline $\begin{array}{c}\text { Independent variable: } \\
\text { Population Density }\end{array}$ & $1.64218 \mathrm{E}-05$ & $5.6501 \mathrm{E}-06$ & 0.00593 \\
\hline \multicolumn{4}{|c|}{ boefficient of Determination $\left(\mathbf{R}^{2}\right)=\mathbf{0 . 1 7}$} \\
\hline
\end{tabular}

a. It was used an Ordinary Least Squares simple regression to illustrate the importance of the population density on MWM Final Results.

b. Statistically significant ( $1 \%$ level).

In fact, a $\mathrm{R}^{2}$ of 0.17 in an extremely reduced sample is an intriguing finding. Other interesting point is that all $\mathrm{p}$-values for such a limited simple linear regression are statistically significant (1\% level).

The means for 'ultra-high' density municipalities are higher than for the others. However, a gap in service provision is observed in every density group of analysis. Fig. 6 shows this behavior.

Consequently, population density seems to be associated with a minimum level of maturity for the local websites evaluated in the study. There were no 'ultra-high' density municipalities with a score lower than 0.52 , which means that there is evidence to believe that huge populations combined with very reduced areas do not produce incomplete local government websites. Table IX shows all 'ultra-high' density municipalities and their MWM Final scores.

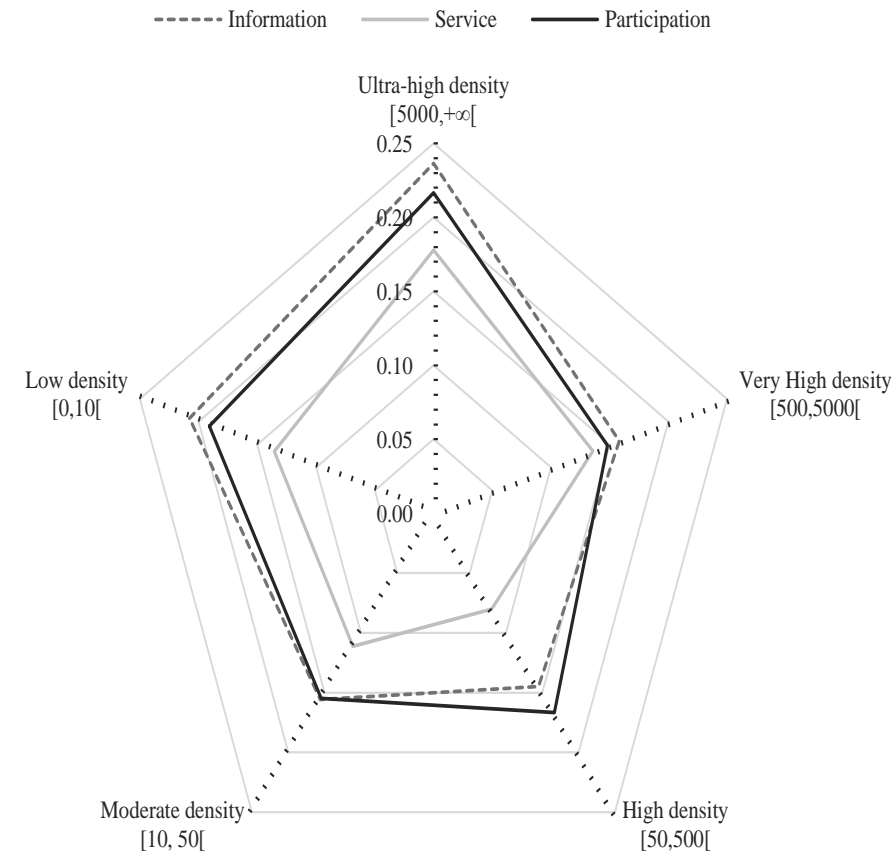

Figure 6. MWM average final results by population density group 
TABLE IX. MWM FINAL RESULTS FOR ULTRA-HIGH DENSITY MUNICIPALITIES

\begin{tabular}{|cc|c|c|}
\hline \multicolumn{2}{|c|}{ Municipality } & $\begin{array}{c}\text { Population Density } \\
\left(\text { people/km }{ }^{2}\right)\end{array}$ & Score \\
\hline Barcelona & ESP & $16,350.88$ & 0.77 \\
Lisboa & POR & $5,114.11$ & 0.77 \\
Madrid & ESP & $5,223.16$ & 0.72 \\
Porto & POR & $5,365.81$ & 0.71 \\
Valencia & ESP & $5,825.36$ & 0.63 \\
Rio de Janeiro & BRA & $5,389.46$ & 0.58 \\
Medellín & COL & $6,307.81$ & 0.55 \\
Melilla & ESP & $6,500.69$ & 0.54 \\
Buenos Aires & ARG & $14,307.68$ & 0.52 \\
São Paulo & BRA & $7,820.53$ & \\
\hline
\end{tabular}

\section{LIMITATIONS}

Measuring maturity is always a complex task. Comparing municipal website maturity in different countries with different geographical arrangements, cultures and political organizations is even more difficult. For this purpose, both populational and geographical criteria were adopted to limit the number of observations. The selected Iberoamerican municipalities tried to capture local website maturity in a cross-national perspective, but these observations only represent a limited part of each country and do not intend to define national e-government maturity instead.

In addition, our goal was just to show the relevance of considering population density in future explanatory works about e-government maturity. We did not intend to build a sophisticated statistical solution to fully explain this phenomenon. Consequently, preliminary results only suggest a correlation to be studied, i.e., population density does not directly explain MWM final scores, but we believe it can be promisingly considered as an important tool to evaluate local website maturity.

\section{CONCLUSIONS}

In this paper, we presented an exploratory study of local egovernment maturity for Andorra, Argentina, Brazil, Chile, Colombia, Portugal and Spain. We concluded that Colombia, Portugal and Spain appeared as the countries with more complete municipal websites when considering an average approach. Nevertheless, as an extension of the findings observed in [4], we also observed an association of the results with a promising variable, the population density.

Despite the fact that we found good MWM results for some municipalities, we can also agree with [7], [22] by saying that local e-government remains substantially underdeveloped in this group of countries and that municipalities seem to favor the development of simpler facilities, instead of providing services or complex participation forms of interaction. In addition, all MWM Final Results were lower than 0.77, inasmuch as these scores are still far from the ideal.

We also verified that the gap between the municipalities with higher scores and the ones with lower scores seems to remain, even for Colombia, Portugal and Spain. In sum, every country presented at least one case of underdeveloped MWM score.

For a good comprehension of the results, two special situations must be quoted here. First, Colombia has a territorial e-government strategy that involves the constant development and improvement of local websites by offering new Information and Communications Technology (ICT) solutions [25], [38]. Second, Chile has a well-established Tax Administration Service - SII (Servicio de Impuestos Internos) that works as an important tool for e-government service dimension and represents a fundamental point to understand why many Chilean municipalities (not all of then provide direct access to SII) scored higher in this dimension [19].

Moreover, it is not clear if population density implies municipal website maturity. Thus, we do not disagree with [10] when they say that city size - or population density in our case - does not explain e-government use. However, we only conclude that this demographic variable must be took into account when evaluating local e-government and suggest that 'ultra-high' density seems to be associated with a minimum level of maturity for local websites. In other words, population density is important to help explaining this phenomenon, but it does not explain it by itself. In fact, we just assume its relevance for modeling local e-government usage and found that huge populations combined with reduced geographic areas do not produce incomplete websites, although 'low' density municipalities may produce enhanced solutions.

Future works may verify if this intriguing and promising variable remains relevant when broadening the number of observations. Even though our results suggest that population density matters, at least for the Iberoamerican observations collected, we still have to find other reasons that help us to explain local e-government maturity as a whole. Many other variables were tested for Portugal and presented interesting results [4]. Consequently, it is possible to use this specific Portuguese approach to enhance the explanatory power of the statistical model adopted here.

Furthermore, a suggestion to enrich primary findings is to increase the number of Iberoamerican municipalities evaluated by analyzing the other nations of the community.

Finally, this paper gives us the opportunity to conclude that there is still room for development in all municipalities evaluated and that population density plays an important role in local e-government and seems to be connected with an implicit minimum level of website maturity.

\section{ACKNOWLEDGMENT}

The authors acknowledge the students enrolled in the course "Digital Government 2014-2015" of the Department of Social, Political and Territorial Sciences of University of Aveiro for the significant contributions while gathering data. 


\section{REFERENCES}

[1] Society of Information Technology Management (Socitm) and Improvement \& Development Agency (IDeA), Local e-government now : a worldwide view. London, UK, 2002

[2] Q. Fan, “An Evaluation Analysis of E-government Development by Local Authorities in Australia," Int. J. Public Adm., vol. 34, no. 14, pp. 926 934, 2011.

[3] M. E. Cook, M. F. LaVigne, C. M. Pagano, S. S. Dawes, and T. A. Pardo, Making a Case for Local E-Government. Albany, NY, USA: Center for Technology in Government, 2011.

[4] G. P. Dias and M. Costa, "Significant socio-economic factors for local egovernment development in Portugal," Electron. Gov. an Int. J., vol. 10, no. 3/4, pp. 284-309, 2013.

[5] K. D. Edmiston, "State And Local E-Government: Prospects and Challenges," Am. Rev. Public Adm., vol. 33, no. 1, pp. 20-45, 2003.

[6] N. Karkin and M. Janssen, "Evaluating websites from a public value perspective: A review of Turkish local government websites," Int. J. Inf. Manage., vol. 34, no. 3, pp. 351-363, 2014.

[7] G. P. Dias and H. Gomes, "Evolution of local e-government maturity in Portugal," Proceedings of the 9th Iberian Conference on Information Systems and Technologies (CISTI). Barcelona, Spain, pp. 1-5, 2014.

[8] R. Cullen, D. O'connor, and A. Veritt, "An Evaluation of Local Government Websites in New Zealand,” J. Polit. Mark., vol. 2, no. 3-4, pp. 184-211, 2003.

[9] G. P. Dias, "Local e-government information and service delivery," Proceedings of the 6th Iberian Conference on Information Systems and Technologies (CISTI). Chaves, Portugal, pp. 1-6, 2011.

[10] J. G. Cegarra-Navarro, J. R. C. Pachón, and J. L. M. Cegarra, "Egovernment and citizen's engagement with local affairs through ewebsites: The case of Spanish municipalities,” Int. J. Inf. Manage., vol. 32, no. 5, pp. 469-478, 2012.

[11] A. M. Sardà, P. M. Rodríguez-Navas, and M. C. Rius, "The information published by local governments. The websites of Catalonia's municipal governments," Rev. Lat. Comun. Soc., vol. 68, pp. 502-528, 2013.

[12] V. Pina, L. Torres, and S. Royo, "E-government evolution in EU local governments: a comparative perspective," Online Inf. Rev., vol. 33, no. 6, pp. 1137-1168, Nov. 2009.

[13] M. Hilbert, "Development trends and challenges for local e-governments: Evidence from municipalities in Chile and Peru," United Nations, 2005. [Online]. Available: http://hdl.handle.net/11362/31922. [Accessed: 13Feb-2015].

[14] L. R. Domínguez, I. M. G. Sánchez, and I. G. Álvarez, "Determining Factors of E-government Development: A Worldwide National Approach,” Int. Public Manag. J., vol. 14, no. 2, pp. 218-248, 2011.

[15] T. Y. Lau, M. Aboulhoson, C. Lin, and D. J. Atkin, "Adoption of egovernment in three Latin American countries: Argentina, Brazil and Mexico," Telecomm. Policy, vol. 32, no. 2, pp. 88-100, 2008.

[16] C.-K. Kim, “A Cross-national Analysis of Global E-government,” Public Organ. Rev., vol. 7, no. 4, pp. 317-329, 2007.

[17] S. K. Aikins and D. Krane, "Are Public Officials Obstacles to CitizenCentered E-Government? An Examination of Municipal Administrators' Motivations and Actions," State Local Gov. Rev., vol. 42, no. 2, pp. 87103, Aug. 2010
[18] G. P. Dias, H. Gomes, and A. Zúquete, "Privacy Policies in Web Sites of Portuguese Municipalities: An Empirical Study," in Advances in Information Systems and Technologies, vol. 206, Á. Rocha, A. M. Correia, T. Wilson, and K. A. Stroetmann, Eds. Berlin - Heidelberg, Germany: Springer Berlin Heidelberg, 2013, pp. 87-96.

[19] L. Kana and F. Barraza, "Taxing time for e-government.," OECD Obs., no. 224 , pp. 50-51, Jan. 2001.

[20] K. Janc, "Geography of Hyperlinks - Spatial Dimensions of Local Government Websites,” Eur. Plan. Stud., pp. 1-19, 2014.

[21] J. Padget, "E-government and e-democracy in Latin America," Intell. Syst. IEEE, vol. 20, no. 1, pp. 94-96, 2005.

[22] C. Salazar C., P. Fernández-Tejeda, and P. Ubeda-Medina, "E-local government: analysis of Internet connections and local government's budgets for e-services development," J. Glob. Compet. Governability, vol. 4, no. 1, pp. 90-101, Jan. 2010.

[23] C. G. Reddick, Handbook of Research on Strategies for Local EGovernment Adoption and Implementation: Comparative Studies (2 Volumes). Hershey, PA, USA: IGI Global, 2009.

[24] K. J. Bwalya and S. F. C. Zulu, Handbook of Research on E-Government in Emerging Economies: Adoption, E-Participation, and Legal Frameworks (2 Volumes). Hershey, PA, USA: IGI Global, 2012.

[25] G. J. Casasbuenas, G. A. Barrera, and M. O. P. Paz, "From the internet for accountability project to the territorial e-government strategy in Colombia," Proceedings of the 3rd International Conference on Theory and Practice of Electronic Governance (ICEGOV). Bogota, Colombia, pp. 315-320, 2009

[26] L. Santos and L. Amaral, Avaliação da presença na Internet das câmaras municipais portuguesas em 2009. Guimarães, Portugal: Gávea University of Minho, 2012.

[27] D. Coursey and D. F. Norris, "Models of E-Government: Are They Correct? An Empirical Assessment," Public Adm. Rev., vol. 68, no. 3, pp. 523-536, 2008.

[28] G. P. Dias, “Q-Model: um modelo bidimensional de maturidade para o egovernment,” Rev. Ibérica Sist. e Tecnol. Informação, vol. 7, pp. 33-46, 2011 .

[29] L. Torpe and J. Nielsen, "Digital Communication between Local Authorities and Citizens in Denmark," Local Gov. Stud., vol. 30, no. 2, pp. 230-244, 2004.

[30] E. Panopoulou, E. Tambouris, and K. Tarabanis, "A framework for evaluating web sites of public authorities," Aslib Proc., vol. 60, no. 5, pp. 517-546, 2008

[31] Departamento de Estadística de Andorra (DE), "Población Estimada por Parroquia." [Online]. Available: http://www.estadistica.ad/serveiestudis/web/banc_dades4.asp?formules= inici\&any $1=01 / 01 / 2014 \&$ any $2=01 / 01 / 2014 \&$ codi_divisio $=2162 \&$ codi_t ema $=2 \&$ lang $=2 \&$ codi_subtemes $=233 \&$ ordre_descripcio $=2$. [Accessed: 28-Jan-2015].

[32] Departamento Administrativo Nacional de Estadística de Colombia (DANE), "Estimación y proyección de población nacional, departamental y municipal total por área 1985-2020." [Online]. Available: http://www.dane.gov.co/index.php/poblacion-ydemografia/proyecciones-de-poblacion. [Accessed: 28-Jan-2015].

[33] Instituto Brasileiro de Geografia e Estatística (IBGE), “Cidades@." [Online]. Available: http://www.cidades.ibge.gov.br/xtras/home.php. [Accessed: 28-Jan-2015]. 
[34] Instituto Nacional de Estadísticas de Chile (INE-CHL), "Reportes Estadisticos Comunales 2012." [Online]. Available: http://reportescomunales.bcn.cl/2012. [Accessed: 28-Jan-2015].

[35] Instituto Nacional de Estadística de España (INE-ESP), "INEbase/Estadísticas territoriales." [Online]. Available: http://www.ine.es/FichasWeb/Welcome.do. [Accessed: 28-Jan-2015].

[36] Instituto Nacional de Estadística y Censos de Argentina (INDEC), "Resultados definitivos Censo 2010 - Consulta por Jurisdición." [Online]. Available: http://censo2010.indec.gov.ar/resultadosdefinitivos.asp. [Accessed: 28-Jan-2015].
[37] Instituto Nacional de Estatística (INE-POR), "População residente estimada 2013 (N.o) por Local de residência (NUTS - 2002), Sexo e Grupo etário; Anual.” [Online]. Available: http://www.ine.pt. [Accessed: 28-Jan-2015].

[38] Ministerio de Tecnologias de la Información y las Comunicaciones de Colombia (MinTIC), "Estrategia Gobierno en línea." [Online]. Available: http://www.programa.gobiernoenlinea.gov.co. [Accessed: 29-Jan-2015]. 